\title{
Software HIDROKSI Development to Detect and Reduce Misconceptions Using Conceptual Change Text Strategy on Salt Hydrolysis
}

\author{
Alvira Dwi Yantia, Sukarmin ${ }^{a,}$ \\ ${ }^{a}$ Chemistry Department, Faculty of Mathematics and Science, State University of Surabaya, Surabaya, \\ Indonesia
}

${ }^{*}$ Corresponding author: sukarmin@unesa.ac.id

Received: February 28, 2021; Accepted: April 07, 2021; Published: April 28, 2021

\begin{abstract}
This research aims to determine the feasibility of software HIDROKSI to detect and reduce students' misconceptions using a conceptual change text strategy on salt hydrolysis. This research used the Research \& Development (R\&D) method with $3^{\text {rd }}$ grade SMAN 1 Krian's student as a subject. The instruments used are student response questionnaires and student activity observations. Software HIDROKSI was developed using the Adobe Flash CS6 Action Script 3.0. The results analyzed using the quantitative descriptive method are as follows: (1) Software HIDROKSI is valid with an average percentage of content validation is $86.67 \%$ and construct validation is $86.22 \%$ (2) The practicability of software HIDROKSI is very practical with an average percentage of student response questionnaire results is $96.61 \%$ (3) The effectiveness of software HIDROKSI in detecting and reducing student's misconceptions is very effective with an average percentage of students' shift in conceptions from misconceptions to knowing concepts is $86.34 \%$.
\end{abstract}

Keywords: software, misconception, conceptual change text, salt hydrolysis

\section{INTRODUCTION}

Chemistry is a branch of science with certain characteristics that are different from other sciences [1]. Chemistry learns about the composition, structure, and properties of matter at a microscopic scale. Chemistry also learns about changes and interactions on the atomic scale to form a new material [2]. Chemical materials have macroscopic characteristics that are tangible to the eye, submicroscopic, tangible but invisible (abstract), and symbolic. Students have difficulty understanding chemistry due to the inability to visualize structures and processes at the submicroscopic level [3].

Chemistry, which is only learned at the macroscopic and symbolic level, makes students use memorization to overcome learning difficulties. Most of the students memorized each concept and did not understand what they were learning [4]. Understanding abstract concepts require formal thinking skills because there are no clear examples. Due to this ambiguity, students have difficulty linking concepts, lead an understanding that is not suitable with the concept is often referred to as a misconception [5] as with one of the materials contained in chemistry, namely salt hydrolysis.

The previous research done by Amelia, et al (2014), shows that $46 \%$ of students experienced misconceptions about salt hydrolysis, especially in the symbolic aspect. Students' misconceptions are spread across all concepts. In the concept of salt hydrolysis $(60.00 \%)$, the concept of acid and base titration and its relation with salt hydrolysis $(42.00 \%)$, the concept of $\mathrm{pH}$ of hydrolyzed salt solution (36.75\%), and the concept of properties of hydrolyzed salt (36,33\%) [6]. Another research done by Arsyad, et al (2016), also reinforces this result shows that students experience misconceptions in (1) linking the notion of acid-base according to experts; (2) determine acids and bases; (3) linking scientific knowledge with their knowledge; (4) understand the scientific language in chemistry; (5) using pH determination calculations; (6) shows a submicroscopic illustration of salt in water; and (7) linking the effects of Ka, Kb, volume, and concentration in the salt solution [4]. Students also experienced the most misconceptions on the meaning of salt hydrolysis and the properties of salt hydrolysis [7]. 
Misconceptions are very dangerous if it keeps on happening. It will hinder students' receiving and assimilating new knowledge to hinder students' success in the learning process [8]. One of the instruments that can be used to identify misconceptions is the Three-Tier Diagnostic Test. Three Tier Diagnostic Test consists of 3 tiers, where the first tier is the choice of answers to the questions. The second tier is the choice of reasons for choosing the answer above. The third tier is the Certainty of the Response Index (CRI) scale. The importance of having $\mathrm{CRI}$ is to identify the confidence level of students' answers in answering each question (test) [9].

Misconceptions can be reduced and even can be cured. Several ways have been developed to reduce misconceptions; one uses an explanatory model analogy, Conceptual Change Text (CCT). The Conceptual Change Text strategy is learning to change students' concept because of the conceptual conflict phase in the learning strategy [10]. In the Conceptual Change Text learning strategy, there are phases that must be known, which are; 1) showing the students' conceptions, 2) creating conceptual conflicts, 3) equilibration processes, 4) concept reconstruction [11]. The process of curing misconceptions by means of CCT is more effective when using media because the results will be identified more quickly.

Gagne stated that the media are one of the types of components in the study environment that can stimulate the students to learn. Meanwhile, according to Briggs, the media is all physical tools that can present messages and stimulate students to learn [12]. Media is one of the tools in learning that can facilitate students' teaching and learning process and reduce misconceptions among students. The role of learning media is very important as ineffective intermediary communication between teachers and students. The results obtained by using the media as a tool to reduce misconceptions will be faster so that misconceptions in students can be resolved immediately [8].

Thus it can be concluded that the detection and reduction of misconceptions with the Conceptual Change Text strategy can run more effectively and efficiently if it is done by using the software. Based on the explanation described, research entitled "Software HIDROKSI Development to Detect and Reduce Misconceptions Using Conceptual Change Text Strategy on Salt Hydrolysis" was developed. The software is named HIDROKSI because HIDROKSI stands for Hidrolisis Deteksi dan Reduksi Miskonsepsi which means Hydrolysis Detection and Reduction Misconception. A general problem can be formulated, namely, "What is the feasibility of the software HIDROKSI for detecting and reducing misconceptions with a Conceptual Change Text strategy on salt hydrolysis based on the validity, practicality, and effectiveness of the software?". This research aims to determine the feasibility of software HIDROKSI to detect and reduce students' misconceptions using a conceptual change text strategy on salt hydrolysis.

\section{METHODS}

\section{Research Design}

The research design used was the research and development (R\&D) method, with stages (1) potential and problems, (2) data collection, (3) product design, (4) design validation, (5) design revision, (6) product testing, (7) product revision (1), (8) trial use, (9) product revision (2), (10) mass production [13]. However, this research is only limited to the 6th stage, with the following flow:

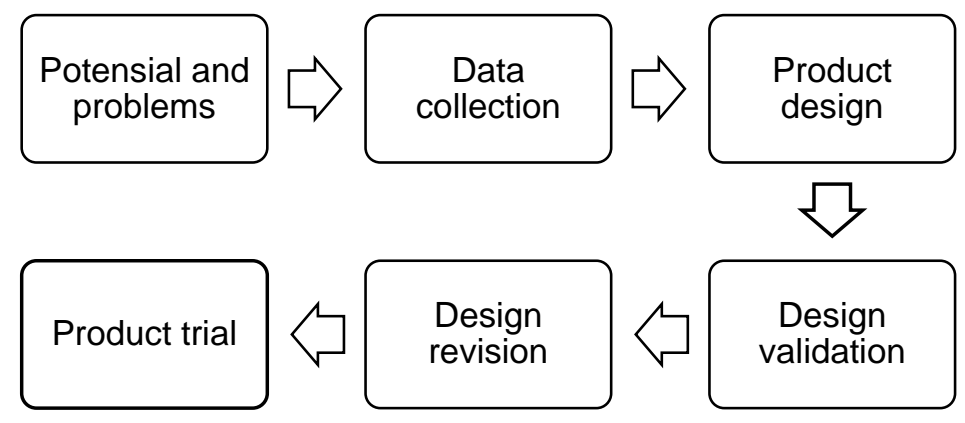

FIGURE 1. Method Steps Research and Development (R\&D) [13]. 


\section{Data Feasibility}

\section{Based on Validation}

To test the validity of the software HIDROKSI, two validation sheet, the content validation sheet, and the construct validation sheet, were used. The content validity is related to the correctness of the material in the software and the suitability of the questions in the software for the purpose. Meanwhile, construct validity is related to the fulfillment of software requirements to detect and reduce misconceptions, compatibility of software displays, and ease of language used in the software. Validation was done by two chemistry lecturers and one chemistry teacher at SMAN 1 Krian. Validators can provide an assessment with a score range of 1-5 in the validation instrument sheet. The analysis of validation data score calculation was carried out using a Likert Scale based on Table 1.

TABLE 1. Likert Score [14]

\begin{tabular}{cc}
\hline Scale & Category \\
\hline 1 & Very Bad \\
2 & Bad \\
3 & Not Good \\
4 & Good \\
5 & Very \\
& Good \\
\hline
\end{tabular}

Then the scale results can be calculated using the formula :

$$
\text { Percentage }(\%)=\frac{\text { score obtained }}{\text { max score }} \times 100 \%
$$

The calculations' results will be interpreted in the score in Table 2, which will be used to determine the validity results of software HIDROKSI.

TABLE 2. Validity Score Interpretation [14]

\begin{tabular}{cc}
\hline Percentage & Category \\
\hline $0 \%-20 \%$ & Invalid \\
$21 \%-40 \%$ & Less \\
$41 \%-60 \%$ & Enough \\
$61 \%-80 \%$ & Valid \\
$81 \%-$ & Very Valid \\
$100 \%$ & \\
\hline
\end{tabular}

\section{Based on Practically}

The practicality of the software HIDROKSI can be obtained from the value of student response questionnaires and the value of student observations. Student response questionnaires were carried out by students who used the software HIDROKSI. Three experts carried out student observations. This value is obtained from the student questionnaire sheet and the student observation of the student activity sheet. Media practicality was assessed using the Guttman scale based on Table 3.

Table 3. Guttman Scale [14]

\begin{tabular}{ccc}
\hline \multirow{2}{*}{ Question } & \multicolumn{2}{c}{ Score } \\
\cline { 2 - 3 } & Yes & No \\
\hline Positive & 1 & 0 \\
Negative & 0 & 1 \\
\hline
\end{tabular}

Then the scale results can be calculated using the formula :

$$
\text { Percentage }(\%)=\frac{\text { score obtained }}{\text { max score }} \times 100 \%
$$

The calculations' results will be interpreted in the score in Table 4, which will be used to determine the validity results of software HIDROKSI. 
TABLE 4. Practically Score Interpretation [14]

\begin{tabular}{cc}
\hline Percentage & Category \\
\hline $0 \%-20 \%$ & Very Lack \\
$21 \%-40 \%$ & Less \\
$41 \%-60 \%$ & Enough \\
$61 \%-80 \%$ & Practice \\
$81 \%-100 \%$ & Very Practice \\
\hline
\end{tabular}

\section{Based on Student Concept Shift}

A test method is utilized to analyze the shift in conception, which is applied to determine the misconceptions that occur on students after using the software HIDROKSI. The method utilized in this test is the Three-Tier Diagnostic Test, which is applied to the pretest and posttest questions. When doing the Three Tier Diagnostic Test, at the first level, students answer multiple-choice questions. At the second level, students choose the answer reasons from the first level. The third level contains students' confidence in answering at levels one and two [9]. The category classification of students' conceptual understanding of the Three-Tier Diagnostic Test is shown in Table 5.

TABLE 5. Three Tier Combination [15]

\begin{tabular}{cccc}
\hline $\begin{array}{c}\text { First } \\
\text { Tier }\end{array}$ & $\begin{array}{c}\text { Second } \\
\text { Tier }\end{array}$ & $\begin{array}{c}\text { Three } \\
\text { Tier }\end{array}$ & Category \\
\hline True & True & Sure & Know Concept (KC) \\
True & False & Sure & Misconception 1 (M1) \\
False & True & Sure & Misconception 2 (M2) \\
False & False & Sure & Misconception (M) \\
True & True & Not & $\begin{array}{c}\text { Don't Know Concept } \\
\text { (DKC) }\end{array}$ \\
& & Sure & Don't Know Concept \\
True & False & Not & (DKC) \\
& & Sure & Don't Know Concept \\
False & True & Not & (DKC) \\
& & Sure & Don't Know Concept \\
False & False & Not & (DKC) \\
& & Sure & \\
\hline
\end{tabular}

The result of the data analysis of the shift in misconceptions can be seen in students who experience a shift in conceptual understanding from misconceptions (M / M1 / M2) to know concepts (KC). Method to identify it is by looking at the results of the shift in misconceptions of students who have worked on pretest and posttest questions in the software HIDROKSI. Then it is calculated using the formula utilized to analyze the results of the shift in misconceptions. The calculation formula utilized is as follows:

$\mathrm{P}(\%)=\frac{\sum \mathrm{MK} \text { to } \mathrm{KC}}{\sum \mathrm{KC}} \times 100 \%$

Desc:

$\mathrm{P}(\%)=$ percentage misconceptions shift.

$\sum M K$ to $K C=$ the number of misconceptions shifts into know concepts.

$\sum \mathrm{KC}=$ number of students' initial misconceptions.

Software HIDROKSI trial was carried out on 15 students in $3^{\text {rd }}$ grade of SMAN 1 Krian. Students' selection was carried out by doing a pretest to determine students who experienced misconceptions, and 15 samples of students who experienced misconceptions about salt hydrolysis were taken. 


\section{RESULT AND DISCUSSION}

\section{Potential and Problems}

Several studies on student misconceptions on salt hydrolysis have been conducted, and the result is that many students experience misconceptions on salt hydrolysis material $[4,6,7]$. Misconceptions in students can cause student difficulties in understanding a concept [5]. Software development for salt hydrolysis is carried out to detect and reduce misconceptions with Conceptual Change Text as a strategy in the salt hydrolysis material from this problem.

\section{Data Collection}

Data collection was carried out through a literature study. It was found that many students had misconceptions about salt hydrolysis. In class XI SMAN 4 Malang, there is $3.11 \%-28.12 \%$ of students experience misconceptions on various sub-concepts of salt hydrolysis. In class XI SMAN 1 Telaga, there is $7.84 \%-31.37 \%$ of students experience misconceptions on various sub-concepts of salt hydrolysis. In class XI SMAN 1 Tangerang, the average percentage of students who experience misconceptions in the salt hydrolysis material is $46 \%$. From previous research results in three different areas, it can be seen that misconceptions in salt hydrolysis material do occur. It causes the researchers to create a solution by developing software HIDROKSI to detect and reduce misconceptions in salt hydrolysis.

\section{Product Design}

At the product design stage, researchers designed software that can be used to detect and reduce student misconceptions with the Conceptual Change Text strategy on salt hydrolysis. Software HIDROKSI is made with the Adobe Flash CS6 Action Script 3.0 application. Software HIDROKSI contain:

Start Page, the start page is a menu of access to the software. It contains the software name and start button to start the software. Students cannot access the software if they don't press the start button. Software HIDROKSI User Manual Page contains instructions for using the software HIDROKSI. Identity Page contains the blank column name, class, and school filled in by students. In the upper right corner of this page, a camera icon aims to command students to take a screenshot or take photos on the page. Students will not be able to go to the next stage if they do not fill out an identity. Pretest Questions Page, after choosing a concept, students are given three pretest questions. Three pretest questions made using the Three Tier Diagnostic Test method. In each question, students will face multiple-choice questions, the reasons for choosing answers to multiple-choice questions, and students' confidence in choosing these answers. Pretest Results Page contains the pretest results that students have done, the results for each question on this page, and the students' pretest results' conclusions. If students are detected with misconceptions or do not understand the concept, they are told and directed to press the next arrow button to go to Conceptual Change Text and improve their conceptions. Conceptual Change Text Page, conceptual Change Text page contains the stages of healing misconceptions. Students are shown that they have experienced misconceptions and the effect of these misconceptions on the next material in the first stage. In the second stage of Conceptual Change Text, students will face text that explains the forms of misconceptions that are often encountered. In the third stage, students are given material in accordance with the experts. In the fourth stage, students are given questions to test whether the healing with Conceptual Change Text is successful and to know if students experience a shift in conceptions from misconceptions to know concepts or students continue to experience misconceptions. Posttest Page contains three posttest questions made using the Three Tier Diagnostic Test method. In each question, students will face multiple-choice questions, the reasons for choosing answers to multiple-choice questions, and students' confidence in choosing these answers. Posttest Results Page contains the results of the posttest students have conducted. There are the student's post-test results and conclusions and a shift in the student's conception of each question on this page. 


\section{Design Validation}

\section{Content Validity}

Tabel 6. Data Content Validation Result

\begin{tabular}{lcc}
\hline \multicolumn{1}{c}{$\begin{array}{c}\text { Assessed } \\
\text { Aspect }\end{array}$} & $\begin{array}{c}\text { Percentage } \\
(\%)\end{array}$ & Category \\
\hline $\begin{array}{l}\text { Truth of } \\
\text { material }\end{array}$ & 85.3 & $\begin{array}{l}\text { Very } \\
\text { Valid }\end{array}$ \\
\hline $\begin{array}{l}\text { Question } \\
\text { suitability }\end{array}$ & 88.9 & $\begin{array}{l}\text { Very } \\
\text { Valid }\end{array}$ \\
\hline
\end{tabular}

Based on the calculation and interpretation of the scale above, the percentage value of content validation is $85,3 \%$ and $88,9 \%$. From this value, the result is an average content validation of $87,1 \%$. This value is included in the very valid category, which means the Three Tier Diagnostic Test used for the pretest and post-test already represents salt hydrolysis material. It can be used to detect student conceptions and in accordance with the existing basic competition in the Ministry of Education and Culture Essential KD. The material in Conceptual Change Text contained in the software HIDROKSI is in accordance with the experts, both from the symbols, numbers, compound formulas, and the compounds' names are correct not to cause misconceptions [16].

\section{Construct Validity}

Tabel 7. Data Construct Validation Result

\begin{tabular}{lcc}
\hline \multicolumn{1}{c}{$\begin{array}{c}\text { Assessed } \\
\text { Aspects }\end{array}$} & $\begin{array}{c}\text { Percentage } \\
\text { (\%) }\end{array}$ & Category \\
\hline $\begin{array}{l}\text { Fulfillment of } \\
\text { software } \\
\text { requirements to } \\
\text { detect and reduce } \\
\text { misconceptions }\end{array}$ & 85.71 & $\begin{array}{l}\text { Very } \\
\text { Valid }\end{array}$ \\
\hline $\begin{array}{l}\text { Display } \\
\text { compatibility }\end{array}$ & 84.44 & $\begin{array}{l}\text { Very } \\
\text { Valid }\end{array}$ \\
\hline $\begin{array}{l}\text { Ease of language } \\
\text { and use of } \\
\text { software }\end{array}$ & 84 & $\begin{array}{l}\text { Very } \\
\text { Valid }\end{array}$ \\
\hline
\end{tabular}

Based on the scale above calculation and interpretation, the construct validation value percentage is $85,71 \%-84,44 \%$. From this value, the average construct validation is $84,71 \%$. This value is included in the very valid category, which means that software HIDROKSI has fulfilled the requirements to become a misconception detection and reduction software. The language is correct and does not give rise to a double interpretation. Language is one of the factors that need to be considered in software. Students will have difficulty understanding the language during learning if the language used is difficult to understand. It can lead to misconceptions in students [17]. The appearance and simplicity of using the software HIDROKSI can be declared valid and feasible for use. Appearance and ease of use are very important for learning software because the software that has an attractive appearance and is easy to use can foster student interest and curiosity, which is one of the basics in developing learning media [18].

\section{Design Revision}

Based on the validation results from two chemistry lecturers and one chemistry teacher at SMAN 1 Krian, several things need to be revised from this software: (1) adding a login page, (2) adding the level of hesitant at stage 2 Conceptual Change Text, (3) adding a camera icon to the pages whose data needs to be saved. 


\section{Product Trial}

Software HIDROKSI trial was carried out on 15 students in $3^{\text {rd }}$ grade of SMAN 1 Krian. Students' selection was carried out by doing a pretest to determine students who experienced misconceptions, and 15 samples of students who experienced misconceptions about salt hydrolysis were taken. Student response data were obtained through a student response questionnaire on the software HIDROKSI. Data from student activity observations were obtained through student observations carried out by observers. The data on the shift in students' misconceptions were obtained from working on the pretest and post-test questions in the software HIDROKSI with the Three-Tier Diagnostic Test method.

\section{Feasibility Analysis Based on Responses}

The results of student responses supported by the results of student activity observations show an average of $96.61 \%$. This result is included in the very practical category, which can be shown in Figure 2 below:

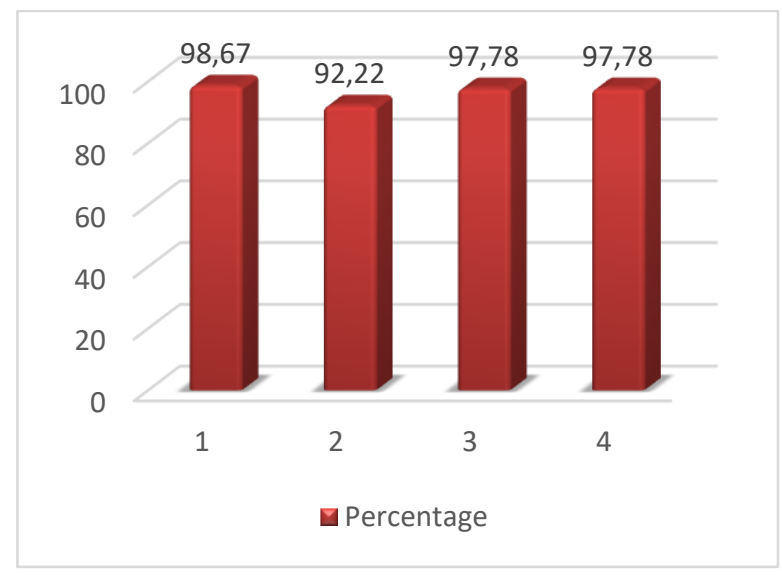

Figure 2. Student Responses

In the first aspect, which is the clarity of the material and its relation to the increase in students' understanding, the percentage result is $98.67 \%$. This value is included in the very practical category. It means that the salt hydrolysis in the conceptual change text of the HIDROKSI software is clear and does not cause confusion to students. In addition, the material on the CCT software HIDROKSI also helps students increase their knowledge of salt hydrolysis.

In the second aspect, the student's interest in software HIDROKSI obtained a percentage of $92.22 \%$. This value is included in the very practical category. It means that students are interested in the software HIDROKSI. These results are supported by observations of student activities that no students leave the room, and no one has missed one or more stages of curing misconceptions during the trial.

In the third aspect, which identifies the simplicity of using the software, the percentage was $97.78 \%$, this value is included in the very practical category. It means that software HIDROKSI is easy to use for students. This result is supported by student activity observation that no student asks about operating software and software buttons during the trial.

In the fourth aspect, which is clarity of the language in the software, the percentage was $97.78 \%$, this value is included in the very practical category. It means that the language in software HIDROKSI is clear, easy to understand, and does not confuse students. These results are supported by observations of student activities that no students ask about the words used in the software HIDROKSI.

\section{Feasibility Analysis Based on Student Concept Shift}

The shift in students' conceptions was obtained from using software HIDROKSI in the form of taking pretest and posttest questions made using the Three Tier Diagnostic Test method. The pretest results can be seen in Figure 3, Figure 4, and Figure 5. 
Basic Theory of Salt Hydrolysis Pretest Result

10

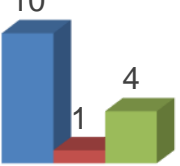

1

$-\mathrm{M}=\mathrm{DKC}=\mathrm{KC}$

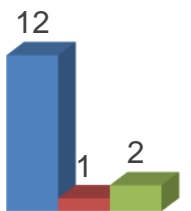

2

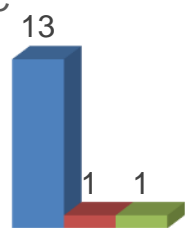

3

Question No.

Figure 3. Basic Theory of Salt Hydrolysis

M: Misconception

KC: Know Concept

DKC: Don't Know Concept

Figure 3 shows that the pretest results from the basic theory of salt hydrolysis concept in question number 1, 9 students experienced misconceptions, two students who did not know the concept, and four students who knew the concept. In question number 2, 13 students experienced misconceptions, one student did not know the concept, and one student knew the concept. In question number 3, 12 students had misconceptions, and three students did not know the concept.

M: Misconception

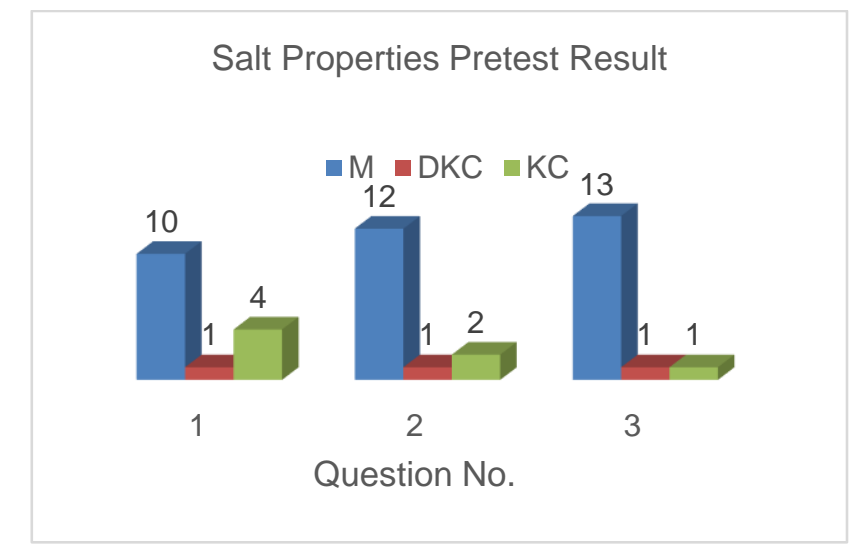

Figure 4. Salt Properties

KC: Know Concept

DKC: Don't Know Concept

Figure 4 shows that the pretest results from the salt properties concept in question number 1,10 students experienced misconceptions, one student did not know the concept, and four students knew the concept. In question number 2, 12 students experienced misconceptions, one student did not know the concept, and two students knew the concept. In question number 3, 13 students experienced misconceptions, one student did not know the concept, and one student knew the concept. 


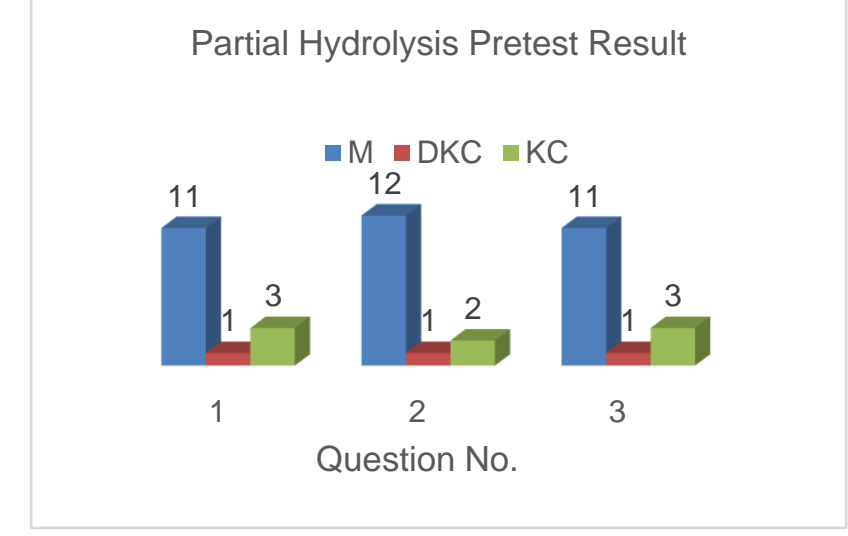

Figure 5. Partial Hydrolysis

M: Misconception

KC: Know Concept

DKC: Don't Know Concept

In Figure 5, it can be seen that the pretest results from the partial hydrolysis concept in question number 1 contained 11 students who experienced misconceptions, one student who did not know the concept, and three students who knew the concept. In question number 2, 12 students experienced misconceptions, one student did not know the concept, and two students knew the concept. In question number 3, 11 students experienced misconceptions, one student did not know the concept, and three students knew the concept.

Students identified with misconceptions will be directed towards the curing process using the Conceptual Change Text strategy, which is contained in software HIDROKSI. Conceptual Change Text is an effective learning strategy in reducing misconceptions because it can make students aware of the misconceptions they experience [19]. In the Conceptual Change Text learning strategy, there are phases that must be known, which are; 1) showing the students' conceptions, 2) creating conceptual conflicts, 3) equilibration processes, 4) concept reconstruction [11]. Students are shown the conceptions they have, namely knowing concepts, not knowing concepts, or misconceptions in the first stage. This stage is useful for showing students the correctness of their concept and its effect on accepting the next concept. In the second stage of Conceptual Change Text, students will face text that explains the forms of misconceptions that are often encountered. It aims to help students realize that their conceptions are different from experts' conceptions to be hesitant about their conceptions. At this stage, there is a scale for students' hesitation about the concept they have. The results of the scale of the level of hesitation must show that students are hesitant about the concepts they have so that the second stage of Conceptual Change Text can be declared to be effective. The third stage aims to make students experience a process of assimilation and accommodation. In this stage, apart from providing supporting facts and illustrations, a description of the correct concept is also provided. The fourth stage is reconstructing the concept of students. In this stage, students are given questions related to the description in the previous stage. It aims to build students' understanding of concepts [20]. The results of the students' level of hesitation can be seen in Table 8 .

Table 8. Students' Level of Hesitant Scale Result

\begin{tabular}{ccccc}
\hline $\begin{array}{c}\text { Confident } \\
\text { Level }\end{array}$ & $\begin{array}{c}\text { Basic Theory } \\
\text { of Salt } \\
\text { Hydrolysis }\end{array}$ & $\begin{array}{c}\text { Salt } \\
\text { Properties }\end{array}$ & $\begin{array}{c}\text { Partial } \\
\text { Hydrolysis }\end{array}$ & Total \\
\hline Not & 1 & 0 & 1 & 22 \\
Hesitant & 2 & 1 & 1 & 4 \\
Less & 5 & 7 & 3 & 15 \\
Hesitant & 6 & 5 & 9 & 20 \\
Enough & 2 & 2 & 1 & 5 \\
Very & 2 & & & \\
Hesitant & & & & \\
\hline
\end{tabular}


The results in Table 4 show that at the level of hesitant, enough, and very hesitant to get higher scores than no hesitant and less. It shows that the second stage in Conceptual Change Text can be effective in causing conceptual conflicts in students.

After passing the Conceptual Change Text stage, the students were tested again for their concept to see the shift in their conceptions. The number of students who experienced misconceptions decreased. It shows that the Conceptual Change Text can cause conceptual changes in students from misconceptions to know concepts. The conditions for conceptual change are dissatisfaction with the current conception, followed by the extent to which new concepts are considered, understood, plausible, and useful [21]. These results are in accordance with previous research investigating Conceptual Change Text to reduce misconceptions [22]. The shift in students' conceptions data was obtained from the pretest and posttest results. The results of the shift can be seen in Table 9.

Table 9. Students' Conception Shift

\begin{tabular}{|c|c|c|c|c|c|c|c|c|c|c|c|c|c|}
\hline \multirow[t]{2}{*}{ No } & \multirow[t]{2}{*}{$\begin{array}{c}\text { Conception } \\
\text { Shift }\end{array}$} & \multicolumn{3}{|c|}{$\begin{array}{c}\text { Basic Theory } \\
\text { of Salt } \\
\text { Hydrolysis }\end{array}$} & \multirow[t]{2}{*}{ Total } & \multicolumn{3}{|c|}{$\begin{array}{c}\text { Salt } \\
\text { Properties }\end{array}$} & \multirow[t]{2}{*}{ Total } & \multicolumn{3}{|c|}{$\begin{array}{c}\text { Partial } \\
\text { Hydrolysis }\end{array}$} & \multirow[t]{2}{*}{ Total } \\
\hline & & 1 & 2 & 3 & & 1 & 2 & 3 & & 1 & 2 & 3 & \\
\hline 1 & KC-KC & 4 & 1 & 1 & 6 & 1 & 1 & 1 & 3 & 3 & 2 & 3 & 8 \\
\hline 2 & $M-K C$ & 8 & 12 & 10 & 30 & 9 & 10 & 12 & 31 & 9 & 9 & 9 & 27 \\
\hline 3 & M-M & 1 & 1 & 2 & 4 & 1 & 2 & 1 & 4 & 2 & 3 & 2 & 7 \\
\hline 4 & DKC-KC & 2 & 1 & 2 & 5 & 4 & 2 & 0 & 6 & 0 & 1 & 0 & 1 \\
\hline 5 & DKC-M & 0 & 0 & 0 & 0 & 0 & 0 & 1 & 1 & 1 & 0 & 1 & 2 \\
\hline 6 & DKC-DKC & 0 & 0 & 0 & 0 & 0 & 0 & 0 & 0 & 0 & 0 & 0 & 0 \\
\hline
\end{tabular}

In the basic theory of salt hydrolysis concept in question number 1 , it can be seen that the shift in students' conceptions occurred from misconceptions to know concepts by 8 out of 9 students. So that the percentage of students' conceptions shift from misconceptions to know concepts is $88.88 \%$. In question number 2, it can be seen that the shift in students' conceptions occurred from misconceptions to know concepts by 12 out of 13 students. So that the percentage of students' conceptions shift from misconceptions to know concepts is $92.3 \%$. In question number 3 , it can be seen that the shift in students' conceptions occurred from misconceptions to know concepts by 11 out of 12 students. So that the percentage of students' conceptions shift from misconceptions to know concepts is $91.67 \%$.

In the concept of salt properties in question number 1 , it can be seen that the shift in students' conceptions occurs from misconceptions to know the concepts by 9 out of 10 students. So that the percentage of students' conceptions shift from misconceptions to know concepts is $90 \%$. In question number 2, it can be seen that the shift in students' conceptions occurred from misconceptions to know concepts by 10 out of 12 students. So that the percentage of students' conceptions shift from misconceptions to know concepts is $83.33 \%$. In question number 3 , it can be seen that the shift in students' conception occurred from misconception to know the concepts by 12 out of 13 students. So that the percentage of students' conceptions shift from misconceptions to know concepts is $92.3 \%$.

In the partial hydrolysis concept in question number 1 , it can be seen that the shift in students' conceptions occurred from misconception to know the concepts by 9 out of 11 students. So that the percentage of students' conceptions shift from misconceptions to know concepts is $81.81 \%$. In question number 2, it can be seen that the shift in students' conceptions occurred from misconceptions to know concepts by 9 out of 12 students. So that the percentage of students' conceptions shift from misconceptions to know concepts is $75 \%$. In question number 3 , it can be seen that the shift in students' conceptions occurred from misconceptions to know concepts by 9 out of 11 students. So that the percentage of students' conceptions shift from misconceptions to know concepts is $81.81 \%$.

Based on previous research, it is known that conceptual change text strategies can reduce misconceptions in students [10]. In addition, it is also known that using software to reduce misconceptions will get more effective results [8]. Some students continue to have misconceptions because they cannot pass the abstract thinking stage, so that those students have difficulty understanding concepts and still experience misconceptions [23]. It is in accordance with Piaget's theory of cognitive development regarding the formal operational stage. When students cannot pass the formal operational stage (abstract thinking), they will have difficulty accepting and understanding the material, so they continue to experience misconceptions. In addition, it is also due to the students' mindset, which is quite solid so that it is difficult 
to change [24].

Another factor is the students' lack of accuracy in understanding the questions' meaning and calculating the questions. In addition, students have low cognitive conflicts, so that the provision of new information will be difficult for students to accept. The conceptual conflict-giving phase becomes the central point of converting student misconceptions into scientific concepts. The greater the level of hesitation students have about the initial concept they have, the more likely they are to receive new information. The conceptual change text given can also affect shifting students' conceptions due to the mismatch of student learning styles, mostly audiovisual, with the Conceptual Change Text model. The illustrations used in these two questions are visual so that students have difficulty obtaining the information provided. The absorption of information depends on how people organize it. If students receive information in accordance with their learning style, the information received will be maximized [20].

\section{CONCLUSION}

Based on the result of student response questionnaires, student observation activity, and shifting students' conceptions from misconceptions to know concepts. It can be concluded that software HIDROKSI is valid, as indicated by the average percentage of content validity, is $86.67 \%$, with the very valid category. The average percentage of construct validity is $86.22 \%$, with a very valid category. The practicality of software HIDROKSI in terms of the student response questionnaire results, supported by the observation of students' activities, obtained an average percentage of $96.61 \%$ with the very practical category. The average percentage of $86.34 \%$ shows HIDROKSI software's effectiveness in detecting and reducing misconceptions in terms of the results of shifting students' conceptions from misconceptions to knowing concepts. Thus, software HIDROKSI is effective to be utilized to detect and reduce students' misconceptions on salt hydrolysis.

\section{ACKNOWLEDGEMENT}

Thank you to the Department of Chemistry, State University of Surabaya, which has become a place for writers to study. Thank you to the experts who have assessed the instrument and development of software HIDROKSI. Thank you to the $3^{\text {rd }}$ grade of SMAN 1 Krian for their contribution to trial the software HIDROKSI.

\section{REFERENCES}

1. L. Mentari, N. Suardana, and I. Wayan, E-Journal Kim. Visvitalis Univ. Pendidik. Ganesha Jur. Pendidik. Kim. 2, 1, 76-87 (2014).

2. C. Wulandari, E. Susilaningsih, and Kasmui, J. Phenom. 8, 2, 165-174 (2018).

3. R.P. Sari and Seprianto, J. Pendidik. Sains Indones. 6, 1, 55-62 (2018).

4. M.A.M. Arsyad, M. Sihaloho, and A. La Kilo, J. Entropi 11, 2, 190-195 (2016).

5. M.S. Muchith, Pembelajaran Konstektual (RaSail Media Group, Semarang, 2008).

6. D. Amelia, Marheni, and Nurbaity, JRPK J. Ris. Pendidik. Kim. 4, 1, 260-266 (2014).

7. N.F. Maratusholihah, R. Sri, and F. Fauziatul, J. Pendidik. 2, 7, 919-926 (2017).

8. A. Ramadhani, Rizki; Hasanudin; D. M., J. Ilm. Mhs. Pendidik. Biol. 4, 1, 1-9 (2016).

9. R. Nurhujaimah, I.R. Kartika, and M. Nurjaydi, J. Penelit. Pendidik. 19, 1, 15-28 (2016).

10. N. Ardyanti and H. Nasrudin, J. Chem. Educ. 3, 2, 261-269 (2014).

11. R. Kumalaningtyas and Sukarmin, UNESA J. Chem. Educ. 8, 3, 420-426 (2019).

12. R. Alfiana and Sukarmin, UNESA J. Chem. Educ. 5, 3, 689-695 (2019).

13. Sugiyono, Metode Penelitian Kuantitatif, Kualitatif Dan R\&D (Alfabeta, Bandung, 2008).

14. Riduwan, Dasar-Dasar Statistika (Alfabeta, Bandung, 2015).

15. H.O. Arslan, C. Cigdemoglu, and C. Moseley, Int. J. Sci. Educ. 34, 11, 1667-1686 (2012).

16. S. Alwi, Itqan 8, 2, 145-167 (2017).

17. N. Nurhidayatullah and A.K. Prodjosantoso, J. Inov. Pendidik. IPA 4, 1, 41-51 (2018).

18. A. Prastya, "Strategi Pemilihan Media Pembelajaran Bagi Seorang Guru" in Problematika Guru Dalam Media, Pros. TEMU IIm. Nas. GURU, pp. 294-302 (Universitas Terbuka, Surabaya, 2016).

19. Zainab and Sukarmin, UNESA J. Chem. Educ. 9, 3, 387-396 (2020).

20. F. Sugiarti and Sukarmin, Unesa J. Chem. Educ. 8, 1, 94-100 (2019). 
21. Syuhendri, " Pengembangan Teks Perubahan Konseptual (TPK) untuk Pengajaran Perubahan Konseptual" in STEM untuk Pembelajaran SAINS Abad 21, Pros. Semin. Nas. Pendidik. IPA, pp. 682-691 (Universitas Sriwijaya, Palembang, 2017).

22. G. Ozkan and G.S. Selcuk, J. Balt. Sci. Educ. 14, 6, 753-763 (2015).

23. N.Y. Mandasari and Sukarmin, UNESA J. Chem. Educ. 9, 3, 344-353 (2020).

24. S. Metal, S.S. Sitompul, and S. Mursyid, J. Pendidik. Dan Pembelajaran Khatulistiwa 7, 9, 1-9 (2018). 